Effect of oestrogen (ethinyloestradiol) on calcium metabolism in patient with hypoparathyroidism treated with dihydrotachysterol (DHT)

\begin{tabular}{|c|c|c|c|c|c|c|c|c|c|c|c|c|c|}
\hline & 24 April & 16 May & 19 May & 5 June & 12 June & 21 June & 22 June & 29 June & 10 July & 17 July & 24 July & 31 July & 4 Sept \\
\hline & \multicolumn{13}{|c|}{ DHT } \\
\hline & \multicolumn{8}{|c|}{$0.35 \mathrm{mg} /$ day } & \multicolumn{2}{|c|}{$0.5 \mathrm{mg} /$ day } & \multicolumn{3}{|c|}{$0.37 \mathrm{mg} /$ day } \\
\hline & \multicolumn{8}{|c|}{$\begin{array}{c}\text { Ethinyloestradiol } \\
(0 \cdot 1 \mathrm{mg} / \text { day })\end{array}$} & & & & & \\
\hline $\begin{array}{c}\text { Serum Ca } \\
(\mathrm{mmol} / \mathrm{l})\end{array}$ & $2 \cdot 33$ & $2 \cdot 33$ & $2 \cdot 30$ & $2 \cdot 05$ & $2 \cdot 03$ & $1 \cdot 80$ & $1 \cdot 78$ & $1 \cdot \overline{68}$ & 1.63 & 1.93 & $2 \cdot 13$ & $2 \cdot 33$ & $2 \cdot 35$ \\
\hline$\underset{(\mathbf{m m o l} / \mathbf{l})}{\operatorname{Serum}} \mathbf{P}$ & $1 \cdot 26$ & $1 \cdot 26$ & 1.45 & $1 \cdot 16$ & $1 \cdot 32$ & 1.58 & 1.45 & 1.58 & $1 \cdot 68$ & 1.65 & 1.52 & $1 \cdot 32$ & $1 \cdot 23$ \\
\hline $\begin{array}{l}\text { Urinary Ca/creat } \\
\left(\frac{\mathrm{mol}}{\mathrm{mol}}\right)\end{array}$ & & 0.62 & $0 \cdot 71$ & 0.57 & $0 \cdot 28$ & $0 \cdot 14$ & 0.06 & & & 0.31 & 0.23 & 0.40 & 0.71 \\
\hline $\begin{array}{l}\text { Urinary OHP/creat } \\
\left(\frac{\mathrm{mol}}{\mathrm{mol}}\right)\end{array}$ & & 0.028 & 0.034 & & & 0.018 & 0.014 & & & 0.029 & 0.020 & 0.023 & \\
\hline $\begin{array}{l}\text { Calcium absorption ("..) } \\
\left(\mathrm{n}=\mathbf{4 0}{ }^{\prime \prime} \pm 13\right)\end{array}$ & & 40 & & & & & 25 & & & & & & \\
\hline
\end{tabular}

Conversion: SI to traditional units-Calcium: $1 \mathrm{mmol} / 1 \approx 4 \mathrm{mg} / 100 \mathrm{ml}$. Phosphate: $1 \mathrm{mmol} / 1 \approx 3.09 \mathrm{mg} / 100 \mathrm{ml}$.

D intoxication. Giving ethinyloestradiol, on the other hand, caused a dramatic fall in a previously well stabilised serum calcium concentration. The hypocalcaemia might have been due to decreased bone resorption, as suggested by the fall in hydroxyproline excretion. Oestrogens could have antagonised DHT-induced bone resorption, since this is the case with other vitamin D metabolites. ${ }^{3}$ The osteolytic effect of parathyroid hormone is not inhibited in hypoparathyroidism. On the other hand, a direct inhibitory effect of oestrogens on bone resorption cannot be excluded, as suggested by studies in rats. ${ }^{4}$ The decrease in intestinal calcium absorption under oestrogens is at variance with the increase noted in postmenopausal women treated with oestrogen. ${ }^{5}$ But in their case secondary hyperparathyroidism is thought to cause the increased absorption. A direct inhibitory effect of oestrogens on calcium absorption may therefore be considered.

Since oestrogens are often spontaneously taken or discontinued by patients themselves those with hypoparathyroidism should be warned of the consequences. Moreover, serum calcium concentrations should be monitored during the menopause in patients with hypoparathyroidism and vitamin $\mathrm{D}$ treatment adapted accordingly.

${ }^{1}$ Burckhardt, P, et al, Hormone Research, 1975, 6, 321.

2 Rinsler, M D, et al, in Radioaktive Isotope in Klinik und Forschung, ed $\mathrm{K}$ Fellinger and $\mathrm{R}$ Höffer, vol 4, p 19. Munich and Berlin, Urban and Schwarzenberg, 1960.

${ }^{3}$ Peacock, M, et al, in Vitamin D, Biochemical, Chemical Aspects Related to Calcium Metabolism, ed A W Norman, p 411. Berlin, New York, De Gruyter, 1977.

4 Weisbrode, S E, and Copen, C C, American fournal of Pathology, 1977, 87, 311.

${ }^{5}$ Gallagher, J L, et al, Frontiers of Hormone Research, 1975, 3, 150.

(Accepted 14 December 1978)

Department of Medicine, Akademisch Ziekenhuis .VUB, Laarbeeklaan 101, 1090 Brussels

D VERBEELEN, $M D$, assistant

Department of Medicine, Hôpital Universitaire Brugmann, 1020 Brussels

M FUSS, MD, registrar

\section{Probable toxic necrosis after prolonged fluspirilene administration}

Nursing staff at one psychiatric hospital have had no difficulty in administering two of the three main long-acting intramuscular antipsychotic drugs-namely, fluphenazine decanoate and flupenthixol decanoate-both of which are held in a vegetable oil base. The third, fluspirilene (Redeptin), which has been commercially available for over three years, is held in aqueous suspension, $2 \mathrm{mg} / \mathrm{ml}$; injections are given once-weekly. The maintenance dose in schizophrenia

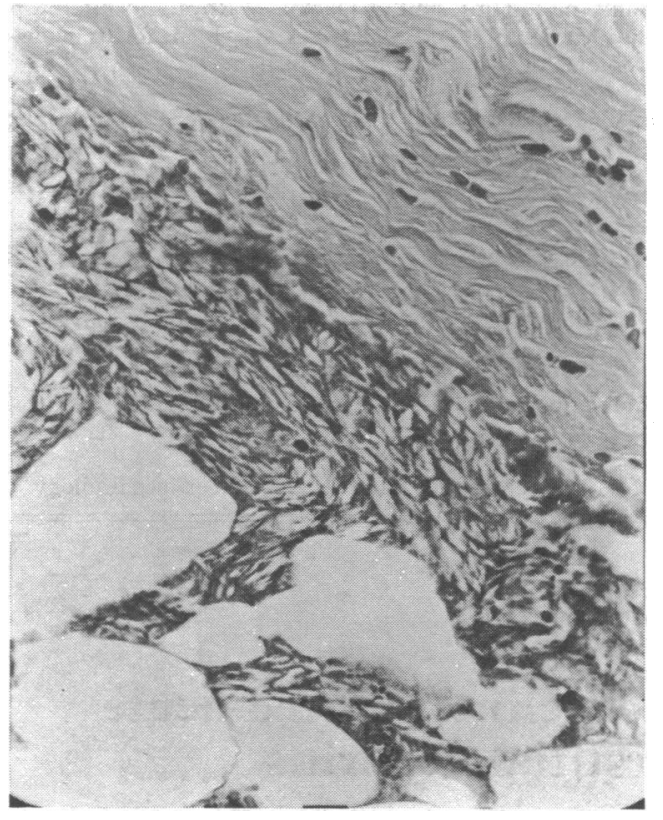

Crystalline clefts between connective tissue and fat at fluspirilene injection site. $(\mathrm{H}$ and $\mathrm{E} . \quad \times 275$.)

varies widely but should not exceed $20 \mathrm{mg} /$ week. In recent months nurses have reported that in several patients increased pressure has been needed to give the injection and lumps have appeared at injection sites. We decided to examine the problem in more detail.

\section{Methods and results}

All patients receiving fluspirilene under the care of two consultant psychiatrists were reviewed; there were 15 women and nine men. In eight cases deep subcutaneous lumps up to $9 \times 3 \mathrm{~cm}$ were palpable at the injection sites, the upper and outer quadrants of the buttocks; their presence was confirmed by the consultant psychiatrists. The lumps, which persisted throughout the week, compelled the nurses in some cases to hunt for a suitable injection site. In a further four patients increased pressure was necessary to give the injection. Nine patients, two with palpable lumps, reported pain or discomfort at the injection site.

One man gave informed consent to excision biopsy of a lump in his buttock. At operation the subcutaneous tissue was hard and contained fibrous gritty material extending down to muscle, the superficial layers of which were affected by a similar process. Routine microscopy of haematoxylin and eosin sections showed numerous sheaves of crystalline material with surrounding hyaline necrosis of fat and connective tissue (see figure). The crystals, not optically active under polarised light, presumably represent spaces left after dissolution of the deposits during processing for microscopy. There were a few small foci of inflammatory-cell infiltrate, possibly related to previous injection tracks, but there was a noticeable absence of infiltrate in the necrotic area surrounding the deposit. The deposits were not intramuscular, and little muscle was present in the specimen. 
The patients who had palpable lumps had been receiving fluspirilene for an average of 26 months, whereas the others had been receiving it for an average of only eight months (Student's $t$ test: $P<0.001$ ). All eight patients with palpable lumps but only three of the other 16 had been on fluspirilene for over a year. At the time of assessment the patients with lumps were receiving a higher weekly dose $(11 \mathrm{mg}$ compared with $7 \mathrm{mg}: \mathrm{P}<0.05)$.

\section{Comment}

Sporadic unpublished reports of "subcutaneous nodules" at the site of fluspirilene injection have been made to the manufacturers. Our findings suggest that the occurrence of deeply placed swellings is more than sporadic but is instead a probable outcome in a patient maintained on the drug for more than 12 months. The cause of the necrosis is not certain. Nevertheless, it seems reasonable to speculate that after injection the aqueous vehicle for fluspirilene is rapidly absorbed, thus allowing precipitation of crystals, which exert a toxic effect. As there was little cellular response the necrosis was almost certainly not due to sensitivity to the drug. A pure pressure effect is also unlikely.

Fluspirilene is an effective antipsychotic with few extrapyramidal side effects. ${ }^{1}$ But unless it can be administered in a more acceptable form its value in long-term maintenance treatment may be limited.

We thank the nursing staff of Gartnavel Royal Hospital, especially Sister M Condie, Mr J Lang, and Sister A McLachlan, for drawing our attention to the problems of administering fluspirilene.

${ }^{1}$ Malm, V, et al, Acta Psychiatrica Scandinavica, 1974, suppl No 249, p 94.

(Accepted 5 Fanuary 1979)

Gartnavel Royal Hospital, Glasgow G12 0XH

R G MCCREADIE, MD, MRCPSYCH, consultant psychiatrist

W E S KIERNAN, FRCP, FRCPSYCH, consultant psychiatrist

Gartnavel General Hospital, Glasgow G12 OYN

R M VENNER, MB, FRCS, senior orthopaedic registrar

Western Infirmary, Glasgow G11 6NT

R B DENHOLM, MB, BSC, senior house officer in pathology

\section{Minocycline-induced acute interstitial nephritis}

The tetracyclines are associated with several renal complications, mainly through their anti-anabolic action. We report here, for the first time, a hypersensitivity-like acute interstitial nephritis assnciated with tetracycline treatment.

\section{Case report}

A 43-year-old housewife presented to her general practitioner two weeks before admission with an upper respiratory tract infection which was treated with minocycline (Minomycin) $250 \mathrm{mg}$ four times a day for five days. Ten days later she developed fever, lethargy, bilateral loin pain, and nausea. The general practitioner prescribed a further course of minocycline but noted proteinuria $(t++)$ and microscopic haematuria (165 erythrocytes $/ \mu \mathrm{l})$. proteinuria $(+++)$ and microscopic haematuria (165 erythrocytes $/ \mu 1)$. kidneys but with very poor dye excretion at 30 minutes.

The patient was referred to the renal unit at Prince Henry's Hospital with a provisional diagnosis of acute glomerulonephritis. On admission she was feverish $\left(38.8^{\circ} \mathrm{C}\right)$ and normotensive $(150 / 80 \mathrm{~mm} \mathrm{Hg})$ with no evidence of oedema. Her fundi were normal and there was mild bilateral loin tenderness. There was no rash and no clinical evidence of uraemia. Investigations showed a haemoglobin concentration of $12.6 \mathrm{~g} / \mathrm{dl}$; leucocytosis $\left(14.3 \times 10^{9} / \mathrm{l}\right)$ with eosinophilia $(9 \%)$; severe renal failure (serum creatinine concentration $700 \mu \mathrm{mol} / 1(7.9 \mathrm{mg} / 100 \mathrm{ml}))$; proteinuria $(0.2 \mathrm{~g} / 24 \mathrm{~h})$; and microscopic haematuria without casts. Obstructive uropathy was excluded on ultrasonography. Percutaneous renal biopsy was performed.

The renal biopsy specimen showed intense interstitial inflammation consisting of histiocytes, lymphocytes, and plasma cells. Some tubules were infiltrated particularly by lymphocytes. Glomeruli appeared essentially normal although scattered mononuclear inflammatory cells were present in some capillary loops.

Immunofluorescence-IgA (Burroughs-Wellcome) was deposited along the

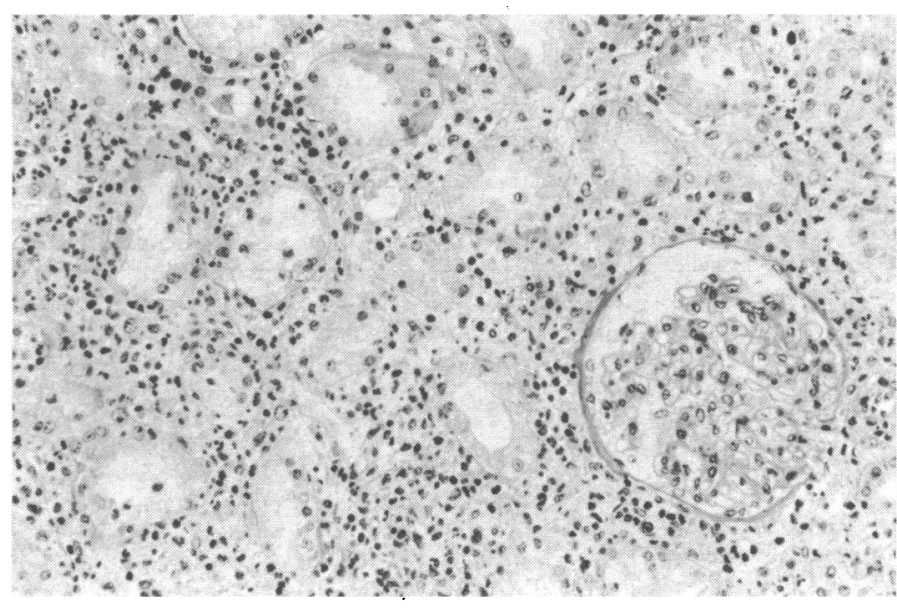

Dense interstitial infiltrate of mononuclear inflammatory cells with occasional cells infiltrating tubular epithelium. (Periodic-acid Schiff. $\times 160$.)

brush border of some proximal convoluted tubules and in some arteriolar walls. C3 was seen in glomerular capillary loops and arteriolar walls.

Apart from withdrawing minocycline and rigidly controlling fluid balance we gave no further treatment. Throughout her stay in hospital the daily urine output exceeded 21 . Her renal function improved spontaneously immediately after admission, and the serum creatinine concentration fell to $150 \mu \mathrm{mol} / 1$ ( $1.7 \mathrm{mg} / 100 \mathrm{ml})$ within six days. At outpatient review two weeks later, renal function was normal (serum creatinine concentration $60 \mu \mathrm{mol} / 1$ $(0.7 \mathrm{mg} / 100 \mathrm{ml}))$, as was urine analysis and urine microscopy.

\section{Comment}

Through their anti-anabolic action tetracyclines (except for doxycycline) may induce severe azotaemia often associated with acidosis and polyuria. A Fanconi-like syndrome of aminoaciduria, glycosuria, acidosis, and proteinuria has also been reported after the use of degraded tetracyclines, ${ }^{1}$ and nephrogenic diabetes insipidus has been described after tetracycline treatment. ${ }^{3}$ The anti-anabolic effects of tetracycline are particularly seen in pregnant women and in patients with pre-existing renal impairment. Although these effects are usually reversible, occasional deaths and cases of irreversible renal damage needing long-term dialysis have occurred. ${ }^{2}$

The isolated hypersensitivity-like acute interstitial nephritis suffered by our patient has not been reported as a complication of tetracycline treatment. Hypersensitivity interstitial nephritis is well documented in association with other antibiotics, such as methicillin and ampicillin. ${ }^{4}$ The typical fever, eosinophilia, polyuria, and renal failure of drug-induced interstitial nephritis were seen in our patient, though she did not develop a rash, which is often reported in this allergic reaction.

The exact pathogenesis of this type of reaction remains undetermined. In methicillin-induced interstitial nephritis a penicilloyl haptenic group may alter the antigenicity of the tubular basement membrane, resulting in the formation of antibodies which react with the tubular basement membrane and stimulate an interstitial inflammatory reaction. IgG and $\mathrm{C} 3$ have been shown along the tubular basement membrane in methicillin-induced interstitial nephritis. ${ }^{5}$ In our patient IgG was not shown, although IgA was observed along the tubular brush border. The importance of this finding is uncertain.

${ }^{1}$ Frimpter, G W, et al, fournal of the American Medical Association, 1963, 184, 111.

${ }^{2}$ Phillips, M E, et al, British Medical fournal, 1974, 2, 149.

3 Casbell, D O, and Sparks, H A, Fournal of the American Medical Association, 1965, 193, 237.

4 Gilbert, D N, et al, Annals of Allergy, 1970, 28, 378.

5 Border, W A, et al, New England fournal of Medicine, 1974, 291, 381.

(Accepted 15 December 1978)

Departments of Nephrology and Histopathology, Prince Henry's Hospital, Melbourne, Victoria

ROWAN G WALKER, MB, FRACP, renal registrar

NAPIER M THOMSON, MD, FRACP, acting director of department of nephrology

JOHN P DOWLING, MB, FRCPA, histopathologist

CHISHOLM S OGG, MD, FRCP, nephrologist 